\title{
Fingernails as a biomarker for dental fluorosis
}

Open acess

${ }^{1}$ Professor, Department of Dentistry, Faculdade Meridional/IMED, Passo Fundo (RS), Brazil

${ }^{2}$ Lutheran University of Brazil,

Canoas (RS), Brazil

${ }^{3}$ Department of Biological Sciences Biochemistry, School of Dentistry of Bauru (FOB/ Bauru), Bauru (SP),

Brazil

\section{Corresponding author:}

lilianrigo@imed.edu.br

Manuscript received: June 2017 Manuscript accepted: November 2017

Version of record online: March 2018

\begin{abstract}
Lilian Rigo', Graziela Oro Cericato', Clarice Sagin Sabadin', Caroline Solda ${ }^{2}$, Débora Nunes Mário ${ }^{1}$, Marília Afonso Rabelo Buzalaf $^{3}$
\end{abstract}

\section{Abstract}

Introduction: Biomarkers indicate levels of a particular chemical agent in the environment studied, which may be useful for monitoring health status, and nails may be major indicators of fluoride.

Objective: To evaluate fluoride concentration in the fingernails of children as a biomarker for fluoride exposure.

Methods: Twenty students were selected, aged 4-5 years old. Their nails were cut at 15 and 45 days (two collections), and the fluoride concentration in the nails was analyzed with the ion-specific electrode (Orion 9409) after rapid diffusion with HDMS.

Results: The total fluoride mean of the samples was $3.68 \mu \mathrm{g} \mathrm{F} / \mathrm{g}$ (sd 1.44), ranging from $1.39 \mu \mathrm{g}$ $\mathrm{F} / \mathrm{g}$ to $7.81 \mu \mathrm{g} \mathrm{F} / \mathrm{g}$. Eleven children (55\%) brush their teeth three times a day, but only three children (15\%) swallow toothpaste.

Conclusion: There is a high prevalence of fluoride exposure in the fingernails of the children studied, presenting risk of developing dental fluorosis in permanent teeth.

Keywords: nails, fluoride poisoning, fluoride, biological marker, dental tooth fluorosis. 


\section{INTRODUCTION}

When used at levels considered optimum, fluoride has shown positive effects on the oral health of the population. Water fluoridation and the greater access to fluoridated dentifrices were major actions for significantly improving the reduction of the dental caries rate ${ }^{1}$. However, excess intake may result in acute and severe poisoning. In Dentistry, the main clinical manifestation from chronic poisoning occurs because of the intake of excessive doses of fluoride during teeth formation, which may cause the appearance of an anomaly called dental fluorosis ${ }^{2}$.

Dental fluorosis is caused by the exposure of the tooth germ to high fluoride ion concentrations (F-1) during the mineralization process ${ }^{3}$. The occurrence and severity of this clinical manifestation may vary among the different individuals and populations because of the influence of environmental and physiological factors, as well as the amount of fluorides ingested and the duration of exposure ${ }^{4,5,6}$.

Regarding the prevalence of dental fluorosis, epidemiological data in Brazil indicate a tendency for increased prevalence and severity of dental fluorosis, presented in the Brazilian Research on Oral Health of 2010 , which identified $16.7 \%$ of cases of fluorosis compared to $8.57 \%$ detected in $2003^{7}$. Other Brazilian studies also reported increased dental fluorosis, as the example of a study performed in Porto Alegre, Rio Grande do Sul, Brazil, in a period of 10 years, which showed an increased prevalence of fluorosis, from $7.7 \%$ to $32.6 \%{ }^{8}$ . On the other hand, Narvai et al. ${ }^{9}$ reported that the prevalence of dental fluorosis in children from the state of São Paulo, Brazil was stationary in 1998, with prevalence of $43.8 \%$, up to 2010 , with prevalence of $38.1 \%$. In the city of Passo Fundo, Rio Grande do Sul, Brazil, a study showed that the prevalence of fluorosis in 633 students

\section{METHODS}

\section{Study design}

The design of this study is experimental and uses children's fingernails for laboratory analysis.

\section{Volunteer selection}

From a total of 35 children enrolled in a State Child Education School located in the city of Passo Fundo, Rio Grande do Sul., in May 2014, we selected by convenience and after the compliance of the inclusion criteria listed hereafter, 20 children. Similar to the sample, the school was selected by convenience because of the easy access.

As inclusion criteria, the children participating in the study should be 4 or 5 years old, considering that in this phase they are under amelogenesis formation of some of their permanent teeth. Participants should also live in the city of Passo Fundo, Rio Grande do Sul., consume water from the public supply of the city since birth, and use fluoridated dentifrice daily.

\section{Pilot test and examiner training}

After the approval from the Research Ethics Committee of Faculdade Meridional (CEP/IMED), of the municipal education network, aged 12 and 15 to 19 years, was $32.8 \%{ }^{10}$. Later, another study performed in a public school of the same city showed a $28.9 \%$ prevalence of dental fluorosis ${ }^{11}$.

Apparently, diseases such as fluorosis and dental caries are in continuous progression in all populations and may be associated with social, economic, and demographic factors, among others. However, fluorosis does not affect everyone who consumes fluoridated water, and when it does, it presents different levels of severity. Thus, the relation between individual and contextual factors and dental fluorosis is still not well established in the literature ${ }^{12}$.

Biomarkers indicate levels of a determined chemical agent in the environment studied, which may be useful to monitor health status and to determine the dose-response relation ${ }^{13}$. According to classifications by the WHO regarding fluoride exposure, the nails are classified as recent markers and may reflect chronic and subchronic exposures to fluoride. The use of nails as fluoride indicators is attractive, considering that it is easy to obtain the samples ${ }^{14}$.

Currently, there are still few scientific evidences using fingernails as sample. Thus, this study aims to improve the knowledge on the excessive fluoride intake by children, observing the importance and relevance of the present research in the city of Passo Fundo, RS, Brazil..

Considering that dental fluorosis has represented a public health problem, the use of biomarkers becomes significant as it helps understanding the rates of fluoride exposure at the maturation period of tooth enamel ${ }^{15}$.

Therefore, the objective is to assess the fluoride concentration in children's fingernails as a biomarker for fluoride exposure.

the researchers were trained and the data collection was validated through a pilot test with four children to verify the method proposed and validate the information analyzed.

\section{Nail collections and setting of fluoride concentrations}

The fluoride concentration in the nails of children was analyzed as follows: the responsible people of the students were instructed to let the left thumbnail of the children to grow for 15 days, allowing the collection later. After 15 days, the same researcher cut the nails with a nail clipper previously sterilized in autoclave; there was one nail clipper for each child. Thirty days after the first collection, the same procedure was repeated for the second collection, which was performed exactly the same way. The nails collected were conditioned in $1.5 \mathrm{~mL}$ sterile plastic tubes.

After nails were collected, they were immersed in special detergent (Ultramet ${ }^{\mathrm{TM}}$ Sonic, Buehler) and distilled and deionized water. The recipients were placed in an ultrasound device for six minutes. Next, the nails 
were put through a sieve and washed in distilled and deionized water, in case any debris remained. The nails were placed in the recipient's lid and taken to the stove for 2 hours at $60^{\circ} \mathrm{C}$. After drying, the nails were stored in aluminum foil for later analysis ${ }^{16}$.

In order to set the rapid microdiffusion with HMDS (hexamethyldisiloxane), described by Taves $^{17}$, the following reagents were used: $\mathrm{NaOH} 1.65 \mathrm{~N}$ (sodium hydroxide), $\mathrm{CH} 3 \mathrm{COOH} 0, \mathrm{Hac} 66 \mathrm{~N}$ (acetic acid), and $\mathrm{HCI}$ 6N/HMDS (hexamethyldisiloxane-saturated hydrochloric acid).

Fragments of nails previously weighed were put on a Petri dish along with $3 \mathrm{~mL}$ of distilled and deionized water. In the plastic lid that was in the center of the dish, fixed with vaseline, $0.1 \mathrm{~mL}$ of $\mathrm{NaOH} 1.65 \mathrm{~N}$ was added. The dishes were sealed and $1.0 \mathrm{~mL}$ of HCI 6N/HMDS was added to each sample through a hole bored in the lids. The holes were readily closed with solid vaseline and plastic film, and the dishes were placed in a horizontal shaker for agitation at speed of $85 \mathrm{rpm}$, at night (minimum of 12 hours and maximum of 15 hours). The fluoride contained in the samples reacted with the HMDS and formed a volatile compound that spread to the $\mathrm{NaOH}$ in the lid

\section{RESULTS}

Data were analyzed by descriptive statistics with the data from demographic variables of the children and from the variable of fluoride concentration in the nails, as Table 1 shows.

From the 20 children of the sample, $55 \%$ were fixed in the center of the dish, where it transformed into trimethylsilanol and fluoride.

In the next day, the dishes were opened and each of their central lids were removed and taken to the stove for 2 hours at $60^{\circ} \mathrm{C}$ so that only the $\mathrm{NaF}$ crystals were left. Next, $0.4 \mathrm{~mL}$ of Hac $0.66 \mathrm{~N}$ was added to a plastic test tube that was sealed with the lid containing the fluoride from the sample. The tube was inverted and vigorously shaken. The Hac dissolved the NaF crystals and left the sample with the optimum $\mathrm{pH}$ for analysis (between 5 and 5.5). The fluoride concentration in the tube was determined by a fluoride-specific electrode (Orion 9609), coupled to the ion analyzer previously calibrated with standards containing 0.01 to $0.08 \mu \mathrm{g} \mathrm{F}$, prepared in the same conditions of the samples. The readings were obtained in $\mathrm{mV}$ and transformed into $\mu \mathrm{g}$ of fluoride using the Excel software (Microsoft). The F- concentration in the nail samples $(\mu \mathrm{g} F / g$ ) was obtained by dividing the $\mu \mathrm{g} F$ found through the weight of the nails.

This study was approved by the Research Ethics Committee of Faculdade Meridional (CEP/IMED), under protocol number $017 / 2011$.

boys and the other $45 \%$ were girls. Half of them (50\%) was 4 years old and the other half was 5 years old. Eleven children $(55 \%)$ brushed their teeth three times a day. However, only three children (15\%) swallowed dentifrice.

The fluoride concentration in the nails of children

Table 1: Descriptive analysis of the demographic variables of the children and the sample of fluoride concentration in the fingernails, Passo Fundo- Rio Grande do Sul, 2014

\begin{tabular}{lcc}
\hline Variables & $\mathrm{n}(20)$ & $\mathrm{n} \%(100)$ \\
\hline Sex & 9 & 45 \\
Female & 11 & 55 \\
Male & & 50 \\
Age & 10 & 50 \\
4 years & 10 & \\
5 years & & 45 \\
Daily toothbrushing frequency & 9 & 55 \\
Once or twice & 11 & \\
3 times & & 15 \\
Swallows dentifrice & 3 & 85 \\
Yes & 17 & 20 \\
No & & 35 \\
Fluoride concentration in the nails & & \\
$1.39-2.62 \mu \mathrm{g} / \mathrm{g}$ & 4 & 20 \\
$3.03-3.47 \mu \mathrm{g} \mathrm{F/g}$ & 7 & 25 \\
$3.97-3.99 \mu \mathrm{g} / \mathrm{g}$ & 4 & \\
$4.71-7.81 \mu \mathrm{g} / \mathrm{g}$ & 5 & \\
\hline
\end{tabular}

was categorized in four groups, according to the frequency distributions: from 1.39 to $2.62 \mu \mathrm{g} \mathrm{F} / \mathrm{g}(20 \%)$, from 3.03 to $3.47 \mu \mathrm{g} \mathrm{F} / \mathrm{g}(35 \%)$, from 3.97 to $3.99 \mu \mathrm{g} \mathrm{F} / \mathrm{g}(20 \%)$, and from 4.71 to $7.81 \mu \mathrm{g} \mathrm{F} / \mathrm{g}(25 \%)$.
The total mean of fluoride concentration in the nails of all samples in both collections was $3.68 \mu \mathrm{g} \mathrm{F} / \mathrm{g}$ (sd 1.44), ranging from $1.39 \mu \mathrm{g} \mathrm{F} / \mathrm{g}$ to $7.81 \mu \mathrm{g} \mathrm{F} / \mathrm{g}$ (Figure 1). 


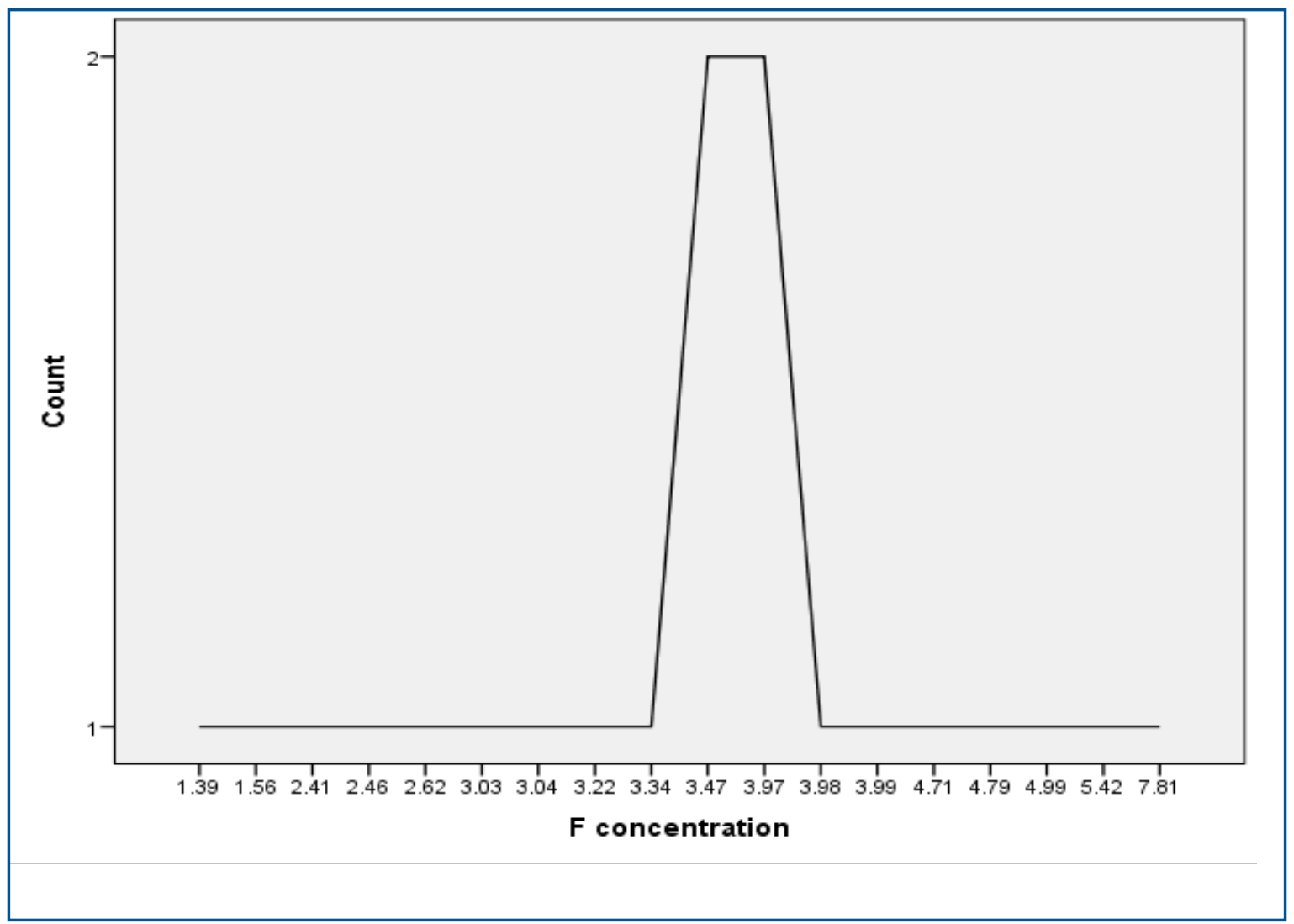

Figure 1: Mean fluoride concentration in the nails of children after the collections, Passo Fundo- Rio Grande do Sul, 2014

\section{DISCUSSION}

The present work aimed to assess fluoride concentration in the fingernails of children as a biomarker for fluoride exposure. Considering fingernails as biomarkers of fluoride exposure that may reflect chronic fluoride exposure ${ }^{14}$ of the children involved in the sample of this study, the risk of developing dental fluorosis in the permanent teeth of the sample studied may be expected. The results of this study showed that the mean fluoride concentrations in the children's nails was high.

Recent studies have shown that fluoride biomarkers may be used to identify the rate of body fluoride, considering that the most researched recent biomarkers are nails and hair, both obtained non-invasively ${ }^{15,20,21}$. Nails, however, have been more featured in studies. The literature shows positive and significant correlations between mean fluoride concentrations in nails and estimated fluoride intake from diet $(\mathrm{r}=0.57)$ in a study performed in two Brazilian cities (Bauru and Itápolis, both in São Paulo, Brazil) ${ }^{16}$. Additionally, other factors such as fluoride concentration in the water, as well as age, sex, and geographic area are mentioned as factors that may influence fluoride concentration in the nails of fingers and toes $^{14}$.

Previous evidences, presented in some scientific studies published from epidemiological surveys on the prevalence of dental fluorosis, show high dental fluorosis rates in children and young people living in the city studied ${ }^{18,19,20}$. The results show a high prevalence of fluorosis $(25 \%$ to $30 \%)$ in different age groups. The authors concluded that tap water - long incorporated with artificial fluoride - consumed by young people was one of the factors associated with dental fluorosis in the model tested in the study ${ }^{19}$. However, in spite of the prevalence, severity is low, meaning low and very low levels ${ }^{18,10,11}$.

Another research that aimed to verify fluoride concentration in the water supply of the city of Passo Fundo, Rio Grande do Sul, Brazil, in 2016, concluded that none of the samples contained more than the acceptable concentration $(0.6$ to $0.9 \mathrm{mg} / \mathrm{L})$ and that the levels of fluoride concentration in the water did not present uniform concentrations in the samples ${ }^{19}$. However, the fluoride accumulation in fluoride doses of dentifrices and in industrialized foods and beverages is established, leading to a summation effect for the cause of fluorosis ${ }^{19}$.

Among the limitations of the technique using fingernails as biomarkers for fluorosis, the literature mentions the cautions regarding external contamination and the establishment of reference values for using the technique as fluorosis predictors ${ }^{15}$. Therefore, in 2012, Buzalaf et al. ${ }^{15}$. suggested this value would be $2 \mu \mathrm{g} \mathrm{F} / \mathrm{g}$, when performing a study in Brazilian children aged 2-7 years. In the same study, the authors showed that children with fluorosis had significantly higher fluoride concentrations in the nails than those without fluorosis, and that the concentrations tend to increase with the severity of fluorosis. In this context, the mean values found in the sample of the present study would indicate a high fluoride concentration in the nails (mean of $3.68 \mu \mathrm{g} \mathrm{F} / \mathrm{g}$ ) with risk of developing dental fluorosis.

It is worth noting that fingernails usually present 
higher fluoride concentrations than other biomarkers ${ }^{4,16,22}$, and a higher blood supply is attributed to this region or a higher growth speed in such nails ${ }^{20}$. Therefore, it is important to develop studies that may clarify the association between fluoride concentration in the nails with the occurrence of dental fluorosis and other associated factors ${ }^{23}$, as well as the possibility of corroborating the present results with other biomarkers such as toenails, especially the thumbnail, and urine ${ }^{24}$. Authors, however, showed that correlation coefficients between total fluoride in fingernails and toenails were slightly higher than the coefficient between the total fluoride intake and fluoride found in urine, confirming the hypothesis that the nails may be slightly better indicators of individual fluoride intake ${ }^{24}$.

The study has some limitations, such as the descriptive design, which does not allow establishing a causality between some of the variables investigated and the result; however, the use of data collected in previous studies in the city reinforces the results found in this research. Moreover, because the sample was selected by convenience, there should be caution when attempting to generalize these results for larger populations.

The contributions of the present study in the field of Collective Health are important, because a prevalent disease may be prevented in the population, which is dental fluorosis. The study will serve as a base for assessing the current situation and for monitoring the dental fluorosis indicators in permanent teeth of adolescents. Furthermore, the study will allow assessing the impact of potential

\section{CONCLUSION}

It is observed that the mean values of fluoride concentration present high concentration of fluoride exposure, which may represent a risk of developing dental fluorosis. changes, which should occur from the development of preventive, educational, and oral health promotional measures in the population.

Therefore, the results found from the method of this research are innovative in the region and even in the country, observing the lack of studies on this topic.

Long-term scientific evidences corroborating the results of this study will be required to later assess the actual impact of the actions performed and the changes of epidemiological indicators of dental fluorosis, locally or nationally.

It is worth noting that fluoride biomarkers are essentially important for investigating the different levels of water fluoridation in the different regions of the country, as well as for controlling fluoride exposure. Thus, regardless of this study having used a sample limited to one specific geographic location and having worked only with fingernails, the results found allow affirming that the implementation of control measures is required to reduce the level of fluoride intake by children living in the location assessed, considering that the amount of fluoride found in the nails of children presented a high mean value.

These actions should include the heterocontrol of fluoride in the water from the local public supply, considering the city does not have such control. They should also include educational and monitoring programs for the effectiveness of children's toothbrushing, including the monitoring of the amount of dentifrice used during toothbrushing $25,26,27$.

Therefore, nails may be considered a biological marker for fluoride exposure.

\section{REFERENCES}

1. Carey CM. Focus on fluorides: update on the use of fluoride for the prevention of dental caries. J Evid Based Dent Pract.. 2014;14(Suppl:95-102). DOI: http://dx.doi.org/10.1016/j.jebdp.2014.02.004

2. Dean HT. Classification of mottled enamel diagnosis. J Amer Dent Assoc. 1934;21(8):1421-6. DOI: https://doi.org/10.14219/jada.archive.1934.0220

3. Moseley R, Waddington RJ, Sloan AJ, Smith AJ, Hall RC, Embery G. The influence of fluoride exposure on dentin mineralization using an in vitro organ culture model. Calcif Tissue Int. 2003;73(5):470-5. DOI: http://dx.doi.org/10.1007/s00223-003-0022-8

4. Carvalho RB, Medeiros UV, Santos KT, Pacheco Filho AC. Influence of different concentrations of fluoride in the water on epidemiologic indicators of oral health/disease. Cienc Saude Coletiva. 2011;16(8):3509-18. DOI: http://dx.doi.org/10.1590/S1413-81232011000900019

5. Buzalaf MA, Pessan JP, Alves KM. Influence of growth rate and length on fluoride detection in human nails. Caries Res. 2006;40(3):231-8. DOI: http://dx.doi.org/10.1159/000092231

6. Khairnar MR, Dodamani AS, Jadhav HC, Naik RG, Deshmukh MA. Mitigation of Fluorosis - A review. J Clin Diagn Res. 2015;9(6):ZE05-9. DOI: http://dx.doi.org/10.7860/JCDR/2015/13261.6085

7. Brasil. Ministério da Saúde. Secretaria de Atenção à Saúde. Departamento de Atenção Básica. Projeto SB Brasil 2010: Condições de saúde bucal da população brasileira 2009-2010: resultados principais. Brasília: Ministério da Saúde; 2011.

8. Maltz M, Silva BB, Schaeffer A, Farias C. Prevalência de fluorose em duas cidades brasileiras, uma com água artificialmente fluoretada e outra com baixo teor de flúor, em 1987 e 1997/98. Rev Fac Odontol Porto Alegre. 2000;41(2):51-5. 
9. Narvai PC, Antunes JLF, Frias AC, Soares MC, Marques RAA, Teixeira DSC, et al. Fluorose dentária em crianças de São Paulo, SP, 1998-2010. Rev Saúde Pública. 2013;47(Supll.3):148-53. DOI: http://dx.doi.org/10.1590/S0034-8910.2013047004715

10. Rigo L, Caldas Junior AF, Souza EHA. Factors associated with dental fluorosis. Rev Odonto Ciênc. 2010;25(1):8-14. DOI: http://dx.doi.org/10.1590/S1980-65232010000100003

11. Rigo L, Sabadin CS, Wietholter P, Solda C, Flores R. Prevalência de fluorose dentária em crianças de uma escola municipal de Passo Fundo/RS. Full Dentistry Sci. 2014;5(19):472-6.

12. Jordão LMR, Vasconcelos DN, Moreira RS, Freire MCM. Dental fluorosis: prevalence and associated factors in 12-year-old schoolchildren in Goiânia, Goiás. Rev Bras Epidemiol. 2015; 18(3):568-77. DOI: http://dx.doi.org/10.1590/1980-5497201500030004

13. Amorim LCA. Os biomarcadores e sua aplicação na avaliação da exposição aos agentes químicos ambientais. Rev Bras Epidemiol. 2003;6(2):158-70. DOI: http://dx.doi.org/10.1590/S1415-790X2003000200009

14. Fukushima R, Rigolizzo DS, Maia LP, Sampaio FC, Lauris JR, Buzalaf MA. Environmental and individual factors associated with nail fluoride concentration. Caries Res. 2009;43(2):147-54. DOI: http://dx.doi.org/10.1159/000211718

15. Buzalaf MA, Massaro CS, Rodrigues MH, Fukushima R, Pessan JP, Whitford GM, et al. Validation of fingernail fluoride concentration as a predictor of risk for dental fluorosis. Caries Res. 2012;46(4):394400. DOI: http://dx.doi.org/10.1159/000339088

16. Levy FM, Bastos JR, Buzalaf MA. Nails as biomarkers of fluoride in children of fluoridated communities. J Dent Child. 2004;71(2):121-5.

17. Taves DR. Separation of fluoride by rapid diffusion using hexamethyldisiloxane. Talanta. 1968; 15(9):969-74.

18. Rigo L, Caldas-Junior AF, Souza EA, Abegg C, Lodi L. Estudo sobre a fluorose dentária num município do sul do Brasil. Cien Saude Colet. 2010;15(Supl.1):1439-48. DOI: http://dx.doi.org/10.1590/S1413-81232010000700055

19. Brito CS, Garbin RR, Mussi A, Rigo L. Vigilância da concentração de flúor nas águas de abastecimento público na cidade de Passo Fundo - RS. Cad Saúde Coletiva. 2016;24(4):452-9. DOI: 10.1590/1414-462X201600040240

20. Lima-Arsati YBO, Martins CC, Rocha LA, Cury JA. Fingernail may not be a reliable biomarker of fluoride body burden from dentifrice. Braz Dent J. 2010;21(2):91-7. DOI: http://dx.doi.org/10.1590/S0103-64402010000200001

21. Pessan JP, Buzalaf MR. Historical and recent biological markers of exposure to fluoride. Monogr Oral Sci. 2011;22:52-65. DOI: http://dx.doi.org/10.1159/000325145

22. Whitford GM, Sampaio FC, Arneberg P, von der Fehr FR. Fingernail fluoride: a method for monitoring fluoride exposure. Caries Res. 1999;33(6):462-7. DOI: http://dx.doi.org/10.1159/000016552

23. Amaral JG, Freire IR, Valle-Neto EFR, Cunha RF, Martinhon CCR, Delbem ACB. Longitudinal evaluation of fluoride levels in nails of 18-30-month-old children that were using toothpastes with 500 and $1100 \mu \mathrm{g}$ F/g. Community Dent Oral Epidemiol. 2014;42(5):412-9.

24. Buzalaf MA, Rodrigues MH, Pessan JP, Leite AL, Arana A, Villena RS, et al. Biomarkers of fluoride in children exposed to different sources of systemic fluoride. J Dent Res. 2011;90(2):215-9. DOI: http://dx.doi.org/10.1177/0022034510385937

25. Villena RS. An investigation of the transverse technique of dentifrice application to reduce the amount of fluoride dentifrice for young children. Pediatr Dent. 2000;22(4):312-7.

26. Vilhena FV, Silva HM, Peres S, Carvalho SH, Caldana ML, Buzalaf MAR. The drop technique: a method to control the amount of fluoride dentifrice used by young children. Oral Health Prev Dent. 2008 6(1):61-5.

27. Cury JA, Caldarelli PG, Tenuta LMA. Necessity to review the Brazilian regulation about fluoride toothpastes. Rev Saude Publica. 2015;49:1-7. DOI: http://dx.doi.org/10.1590/S0034-8910.2015049005768 


\section{Resumo}

Introdução: Os biomarcadores indicam níveis de determinado agente químico no meio estudado, os quais podem ser úteis ao monitoramento do estado de saúde, podendo as unhas serem importantes indicadores de flúor.

Objetivo: Avaliar a concentração de flúor nas unhas das mãos de crianças como biomarcador de exposição ao flúor.

Método: Foram selecionadas 20 escolares, com idade entre 4 e 5 anos. As unhas foram cortadas aos 15 e 45 dias (duas coletas) e a concentração de flúor nas unhas foi analisada com o eletrodo íon específica (Orion 9409), após difusão facilitada por HDMS.

Resultados: A média total de flúor das amostras foi de 3,68 $\mu \mathrm{g} \mathrm{F/g} \mathrm{(dp} \mathrm{1,44),} \mathrm{variando}$ de $1,39 \mu \mathrm{g} \mathrm{F/g}$ a $7,81 \mu \mathrm{g} \mathrm{F/g}$. Onze crianças (55\%) escovam os dentes três vezes por dia, porém, somente três crianças (15\%), engolem dentifrício.

Conclusão: Há uma alta prevalência de exposição ao flúor nas unhas das mãos das crianças investigada com risco de desenvolver fluorose dentária nos dentes permanentes.

Palavras-chave: unhas, intoxicação por flúor, flúor, marcador biológico, fluorose dentária.

๑ The authors (2018), this article is distributed under the terms of the Creative Commons Attribution 4.0 International License (http://creativecommons.org/licenses/by/4.0/), which permits unrestricted use, distribution, and reproduction in any medium, provided you give appropriate credit to the original author(s) and the source, provide a link to the Creative Commons license, and indicate if changes were made. The Creative Commons Public Domain Dedication waiver (http://creativecommons.org/publicdomain/ zero/1.0/) applies to the data made available in this article, unless otherwise stated. 